\title{
DIAGNOSTIC SIGNIFICANCE OF LACTOBACILLUS SPP. IDENTIFICATION IN EJACULATE
}

Pochernikov DG ${ }^{1}$, Postovoytenko NT'1 , Getman W'1 , Galkina IS²

1 Ivanovo State Medical Academy, Ivanovo, Russia

${ }^{2}$ Federal Research Institute for Health Organization and Informatics, Moscow, Russia

Popularization of the real-time polymerase chain reaction method (RT-PCR), which is a trend of the recent years, allowed to significantly expand of the range of microorganisms that can be detected in the genitourinary tract of men. Moreover, the available picture of the microbiome's bacterial component structure became more detailed. Lactobacillus spp. remains one of the least studied groups of microorganisms. Treating patients with reproductive disorders, the authors have accumulated clinical experience demonstrating the possible relationship between presence of Lactobacillus spp. in the ejaculate and changes in the level of sex hormones and the key values registered with a spermogram. This study aimed to compare the levels of luteinizing hormone, follicle-stimulating hormone, testosterone, estradiol, prolactin, progesterone, and sex hormone binding globulin (SHBG) in blood serum and changes in spermogram values in 210 men with and without Lactobacillus spp. detected in their ejaculate. The treatment group included 105 men whose ejaculate had Lactobacillus spp. in the amount of (Lg) $\geq 10^{3}$, as detected by RT-PCR. The control group included 105 men whose ejaculate did not have Lactobacillus spp. detected; the microbiome's bacterial component structure of their ejaculate was normal. Compared to the control group, treatment group had hormonal disorders registered more often: abnormal levels of three or more hormones ( $p=0.04)$, hyperestradiolemia $(p=0.05)$, increased level of SHBG $(p=0.01)$. It was established that the presence of Lactobacillus spp. in the ejaculate of treatment group participants is associated with oligoastenoteratozoospermia $(p<0.01)$, decreased concentration of spermatozoa $(p=0.01)$, their decreased motility $(p<0.01)$ morphology abnormalities $(p<0.01)$. Thus, the presence of Lactobacillus spp. in the ejaculate can be interpreted as an additional marker of hormonal imbalance and fertility dysfunction in men.

Keywords: Lactobacillus spp., lactobacilli, ejaculate, male infertility, ejaculate microflora, Androflor, pathospermia, oligoastenoteratozoospermia, hyperestradiolemia, hyperprosterolemia

Author contribution: Pochernikov DG — research planning, literature analysis, data interpretation and analysis, manuscript drafting, preparation of the final version of the article; Postovoytenko NT — literature analysis, data collection, analysis and interpretation, manuscript drafting, preparation of the final version of the article; Getman W - data collection, analysis and interpretation, manuscript drafting; Galkin IS — research planning, data interpretation, manuscript drafting, preparation of the final version of the article.

Compliance with ethical standards: the study was approved by the Ivanovo State Medical Academy ethics committee and is a part of the earlier research (protocol № 5 of June 03, 2009). All patients signed a voluntary informed consent to participate in the study.

Correspondence should be addressed: Denis G. Pochernikov

Sheremetevsky prospekt, 8, Ivanovo, 153012; urologkmn@mail.ru

Received: 29.05.2020 Accepted: 17.06.2020 Published online: 29.06.2020

DOI: $10.24075 /$ brsmu.2020.039

\section{ДИАГНОСТИЧЕСКАЯ ЗНАЧИМОСТЬ ВЫЯВЛЕНИЯ LACTOВACILLUS SPP. В ЭЯКУЛЯТЕ}

\section{Д. Г. Почерников ${ }^{1 凶}$, Н. Т. Постовойтенко ${ }^{1}$, В. В. Гетьман ${ }^{1}$, И. С. Галкина}

1 Ивановская государственная медицинская академия, Иваново, Россия

2 Центральный научно-исследовательский институт организации и информатизации здравоохранения, Москва, Россия

В последние годы благодаря внедрению метода полимеразной цепной реакции в реальном времени (ПЦР-РВ) значительно расширился спектр микроорганизмов, выявляемых в мочеполовом тракте мужчин, детализировано представление о структуре бактериальных компонентов микробиома. Одной из наименее изученных групп микроорганизмов остается Lactobacillus spp. При ведении пациентов с репродуктивными нарушениями авторами накоплен клинический опыт, демонстрирующий возможную взаимосвязь изменения уровня половых гормонов и основных показателей спермограммы c наличием Lactobacillus spp. в эякуляте. Целью работы было сравнить уровни лютеинизирующего гормона, фолликулостимулирующего гормона, тестостерона, эстрадиола, пролактина, прогестерона, а также глобулина, связывающего половые гормоны (ГСПГ), в сыворотке крови и изменения показателей спермограммы у 210 мужчин при выявлении в эякуляте Lactobacillus spp. и при их отсутствии. В основную группу были включены 105 мужчин, в эякуляте которых по данным ПЦР-РВ выявлены Lactobacillus spp. в количестве (Lg) $\geq 10^{3}$. Контрольная группа включала 105 мужчин, у которых отсутствовали Lactobacillus spp. и структура бактериального компонента микробиома эякулята соответствовала норме. В основной группе по сравнению с контрольной у мужчин чаще встречались гормональные нарушения: отклонение от нормы уровней трех и более гормонов ( $p$ = 0,04), гиперэстрадиолемия ( $p=0,05)$ и повышение уровня ГСПГ ( $p=0,01)$. Установлено, что наличие Lactobacillus spp. в эякуляте мужчин основной группь ассоциировано с олигоастенотератозооспермией ( $p<0,01)$, со снижением концентрации сперматозоидов ( $p=0,01)$, с ухудшением их подвижности ( $p<0,01)$ и нарушением морфологии ( $<$ 0,01). Таким образом, присутствие в эякуляте Lactobacillus spp. может служить дополнительным маркером нарушения гормонального фона и фертильности у мужчин.

Ключевые слова: Lactobacillus spp., лактобактерии, эякулят, мужское бесплодие, микрофлора эякулята, «Андрофлор», патоспермия олигоастенотератозооспермия, гиперэстрадиолемия, гиперпрогестеронемия

Вклад авторов: Д. Г. Почерников - планирование исследования, анализ литературы, интерпретация и анализ данных, подготовка черновика рукописи, подготовка финального варианта статьи; Н. Т. Постовойтенко - анализ литературы, сбор, анализ и интерпретация данных, подготовка черновика рукописи, подготовка финального варианта статьи; В. В. Гетьман - сбор, анализ и интерпретация данных, подготовка черновика рукописи; И. С. Галкина - планирование исследования, интерпретация данных, подготовка черновика рукописи, подготовка финального варианта статьи.

Соблюдение этических стандартов: работа одобрена этическим комитетом Ивановской государственной медицинской академии и является фрагментом начатого ранее исследования (протокол № 5 от 03 июня 2009 г.). Все пациенты подписали добровольное информированное согласие на участие в исследовании.

$\triangle$ Для корреспонденции: Денис Геннадьевич Почерников Шереметевский проспект, д. 8, г. Иваново, 153012; urologkmn@mail.ru

Статья получена: 29.05.2020 Статья принята к печати: 17.06.2020 Опубликована онлайн: 29.06.2020

DOI: $10.24075 /$ vrgmu.2020.039 
Currently, there is no consensus among the researchers as to what is the normal composition of men's urogenital tract microflora [1]. Clinical recommendations of the recent years suggest performing only the cultural analysis of the ejaculate of infertile men or preconception patients [2-4]. However, this method does not fully uncover the specifics of a man's urogenital microbiota: it does not allow identification of uncultivated microorganisms, e. g., obligate anaerobic and some facultative anaerobic ones, including lactobacilli [5, 7-10]. According to the leading European and Russian urologists, prostatitis diagnostics should include a two-glass test, ejaculate bacterial examination and additional RT PCR examination thereof [3, 5, 7-10]. In the recent years, popularization of the advanced diagnostic methods allowed to significantly expand the range of microorganisms detected in the urogenital tract of men and women [1, 8, 11-13]. In our opinion, one of the promising methods is RT-PCR performed with the Androflor testing kit for men; the method allows uncovering both the qualitative and the quantitative composition of the ejaculate microbiota, including lactobacilli [5, 7, 9, 10, 14-19].

Among the published papers, there are but a few publications addressing the occurrence of lactobacilli in various biotopes of the genitourinary tract of men. According to several researchers $[16,19,20]$, Lactobacillus spp. is one of the most common genus of microorganisms found both in healthy men and those with urethritis or prostatitis; the bacteria are identified by the bacteriological method [21], 16S rRNA sequencing [6, 20] and RT-PCR [5, 8, 14, 16, 19]. Thus, Lactobacillus spp. bacteria were detected in $9-73.3 \%$ of samples of ejaculate of infertile men and those examined as part of a preconception course $[5,6,8,16]$. One study reported registering a statistically significant correlation between the presence of lactobacilli in the urethra and hormonal disruptors in the seminal fluid of infertile men, which is especially interesting [19].

Some papers highlight the link between the presence of lactobacilli in the ejaculate and normal characteristics of the semen as registered by a spermogram. The research showed that normal sperm morphology can coexist with an increased relative content of Lactobacillus spp. in semen samples [22]. Moreover, there was detected a positive correlation between the presence of lactobacilli in semen and normal sperm characteristics [23].

The least studied to date are Lactobacillus spp. bacteria taken from men who observed the biomaterial donation rules, i.e. abstained sexually or used barrier contraception to reduce the risk of receiving lactobacilli from a vagina. According to a number of researchers, in most cases, Lactobacillus spp. are transient microflora of a man's genitourinary tract $[7,10,14,17]$. Lactobacilli can play the part of a probable microbial agent that promotes emergence and persistence of a chronic inflammation of the prostate gland [24]. In the recent years, the role of hormonal changes, in particular, the effect of testosterone levels on bacterial contamination of the prostate gland secretion, has been discussed increasingly often $[25,26]$. However, analyzing the literature available to us we failed to discover data pointing to the correlation between the key fertility hormones - estradiol, prolactin, progesterone, and SHBG, traditionally examined in men with reproductive disorders [2-4], - with infectious agents identified in prostate secretions or ejaculate.

Results of a pilot study translated into a patent for an invention we obtained [27]. The essence of the discovery is that the presence of Lactobacillus spp. in the ejaculate with the bacterial titer of $(\mathrm{lg}) \geq 10^{3}$ can be interpreted as an additional marker of hormonal disorders and thus call for further extended examination of the man. The subject of this research is extremely relevant since there is no data describing the effect high content of lactobacilli has on the men's sperm fertility. This study aimed to compare the levels of LH, FSH, testosterone, estradiol, prolactin, progesterone, SHBG in serum and the key sperm property indicators in men with Lactobacillus spp. detected and not.

\section{METHODS}

The comparative prospective study lasted from November 2016 to July 2019 and included 210 men that visited urological clinic of the Ivanovo State Medical Academy seeking treatment for infertility, preconception course and/or having a concomitant erectile dysfunction. The inclusion criteria were: male, reproductive age; infertility or preconception preparation course; no hormonal and antibacterial drugs, as well as any other medicines, taken within the last 4 weeks. The exclusion criteria were: hypogonadotropic and hypergonadotropic hypogonadism, diabetes mellitus, hypo- and hyperthyroidism; sexually transmitted infections and clinical manifestations of prostatitis, such as pain and dysuria; karyotype abnormalities, CFTR gene mutations, microdeletions in the AZF locus of $Y$ chromosome.

All men had their ejaculate examined with the help of the Androflor testing kit (RT-PCR); their serum was examined to determine the levels of luteinizing hormone (LH), folliclestimulating hormone $(\mathrm{FSH})$, total testosterone, estradiol, prolactin, progesterone, and sex hormone binding globulins (SHBG), free androgen index (FAl), testosterone to estradiol ratio (TER), which are typically checked during examination of infertile men or men undergoing a preconception course [2, 3]. Blood samples for the hormone concentration study were taken in the morning, from 8 to $10 \mathrm{am}$; the patients had to abstain from eating any food before sample taking. They were also not

Table 1. Level of the hormones studied in the two compared groups

\begin{tabular}{|c|c|c|c|c|}
\hline Hormone in serum hormone & Reference values & $\begin{array}{l}\text { Group with Lactobacillus spp. } \\
\qquad(n=105), \text { mean } \pm \text { STD }\end{array}$ & $\begin{array}{l}\text { Group without Lactobacillus } \\
\operatorname{spp}(n=105), \text { mean } \pm \text { STD }\end{array}$ & $p$ \\
\hline LH, mIU/ml & $1-12$ & $5.1 \pm 2.1$ & $4.4 \pm 2.0$ & 0.09 \\
\hline $\mathrm{FSH}, \mathrm{mlU} / \mathrm{ml}$ & $0.9-12$ & $5.2 \pm 2.5$ & $4.5 \pm 2.7$ & 0.1 \\
\hline Prolactin, ng/ml & $4-15$ & $14.1 \pm 7.8$ & $12.8 \pm 5.9$ & 0.3 \\
\hline Progesterone, ng/ml & $0.05-0.15$ & $0.23 \pm 0.14$ & $0.25 \pm 0.17$ & 0.3 \\
\hline Estradiol, pg/ml & $11-43$ & $26.5 \pm 13.5$ & $23.4 \pm 9.9$ & 0.04 \\
\hline Testosterone ng/ml & $3.5-9$ & $5.3 \pm 2.6$ & $5.1 \pm 2.5$ & 0.2 \\
\hline SHBG, nmol/l & $18-54$ & $41.1 \pm 23.2$ & $35.8 \pm 20.7$ & 0.08 \\
\hline FAI, \% & $15-102$ & $51.6 \pm 23.3$ & $51.3 \pm 27.6$ & 0.5 \\
\hline $\mathrm{T} / \mathrm{E}_{2}$ ratio & 83 and above & $232.8 \pm 134.4$ & $252 \pm 157.1$ & 0.2 \\
\hline
\end{tabular}




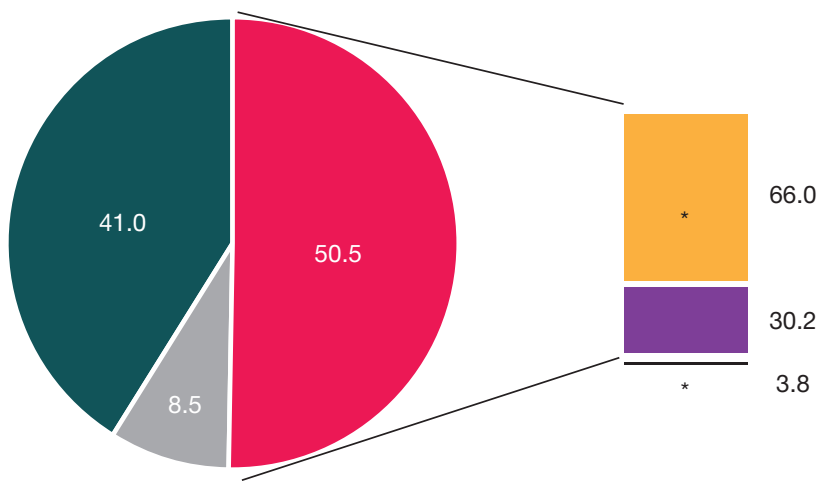

Change in the level of one hormone

Change in the level of more than one hormone

Within reference values
Change in the level of three hormones

Change in the level of two hormones

Change in the level of four hormones

Fig. 1. Hormonal changes in the group with Lactobacillus spp., $n=105$

supposed to have sexual intercourses for 24 hours before the procedure.

All men were divided into two groups, randomized by age, body mass index, alcohol intake and smoking status, complaints, established diagnosis and serum testosterone level (in order to exclude its influence on the bacterial content of the ejaculate) $[25,26]$. The treatment group included 105 men whose ejaculate had Lactobacillus spp., titer of $(\mathrm{Lg}) \geq 10^{3}$, as detected by RT-PCR. The control group included 105 men whose ejaculate did not have Lactobacillus spp. detected; the microbiome's bacterial component structure of their ejaculate was normal, as registered with the Androflor testing kit. The average age of the treatment group patients was $35.5 \pm 8.1$ years, that of the control group patients $35.8 \pm 8.3(p>0.05)$. Before biomaterial sample collection, all patients urinated, thoroughly cleaned their external genitalia (without antiseptics), and masturbated to deliver the ejaculate samples into sterile polymer containers. The containers were delivered to the laboratory within one hour from collection or less.

For RT-PCR examination, we used the DT-96 detection amplifier (DNK-Tekhnologiya; Russia) [28] and the Androflor testing kit (medical product registration certificate RZN 2016/4490 of 07.25.2016). For the hormone concentration study we took $5 \mathrm{ml}$ of venous blood from each participant.
The samples were collected from 8 am to 10 am under aseptic conditions, the blood put into $5 \mathrm{ml}$ tubes. After coagulation, the liquid part was transferred to clean sterile tubes, centrifuged in a laboratory centrifuge for $10 \mathrm{~min}$ at $1500 \mathrm{rpm}$, then the supernatant was transferred to disposable plastic Eppendorf tubes. Hormone concentration was determined with the help of Roche Cobas e8000 602 analytical system (Roche Diagnostics; Sweden). Table 1 contains reference levels of the hormones studied. Ejaculate samples were studied with the help of the SQA-V analyzer (Medical Electronic System Ltd.; Israel). The amount of leukocytes in semen was determined by staining smears with Leukodif 200 dyes (Erba Lachema; Czech Republic); assessing the quantitative and qualitative indicators, we relied on the normal values approved by WHO (2010) [29]. Microsoft Excel 2013 and Statistica 12.0 (Stat Soft Inc.; USA) software packages enabled statistical analysis. Wilcoxon and Fisher tests were applied to determine reliability of the data obtained; the differences were considered significant at $p \leq 0.05$.

\section{RESULTS}

Nine (8.5\%) patients of the treatment group (with Lactobacillus spp. detected) had the levels of all studied hormones corresponding to the reference values. In the control group, the

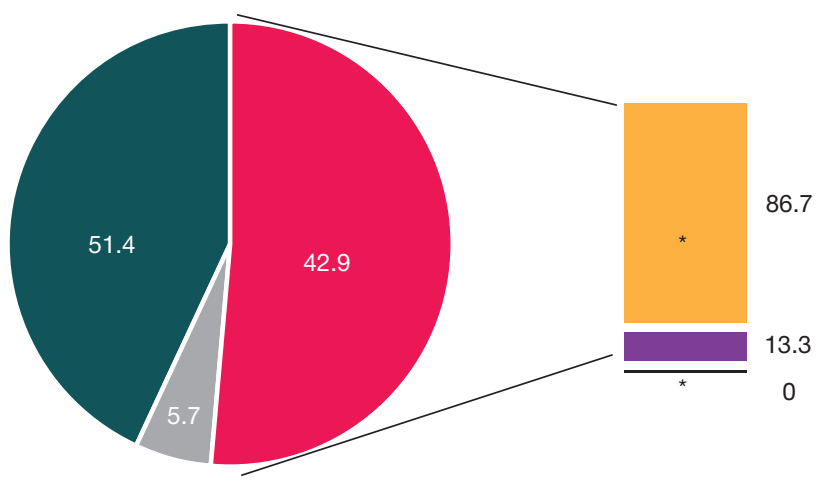

Change in the level of one hormone

Change in the level of more than one hormone

Within reference values
Change in the level of three hormones

Change in the level of two hormones

Change in the level of four hormones

Fig. 2. Hormonal changes in the group without Lactobacillus spp., $n=105$ 


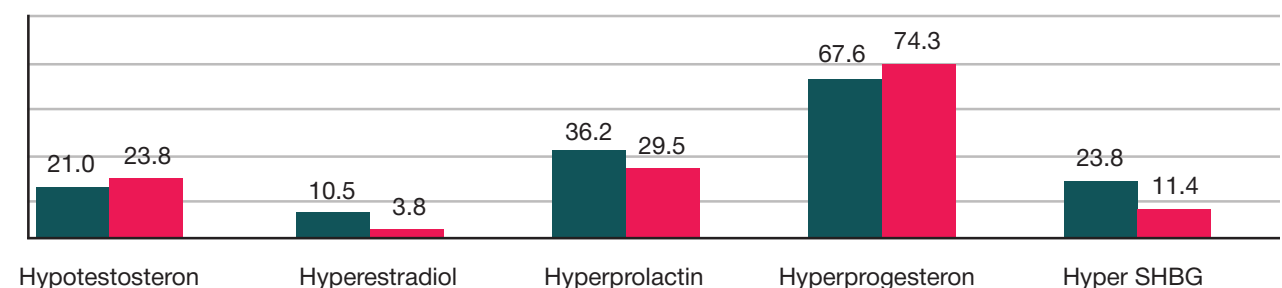

Group of men with Lactobacillus spp., $n=105$

Group of men with normal flora, $n=105$

Fig. 3. Changes in the hormones studied, two compared groups

number of such patients was $6(5.7 \%)(p>0.05)$. Combined hormonal disorders were more common in the treatment group (50.5\% versus $42.9 \% ; p>0.05$ ) than in the control group (Fig. 1 and 2, respectively). Men with lactobacilli had more pronounced hormonal disturbances in the form of deviations from the normal levels of three or more hormones, the difference with the values registered in the control group significant $(p=0.04)$.

Table 1 contains the average hormone levels registered in the two groups. The group with Lactobacillus spp. had their average level of estradiol significantly different from that registered in the control group. Treatment group patients were also likely to have increased levels of prolactin and SHBG. Higher SHBG level and hyperestradiolemia were discovered in the treatment group more often $(23.8 \%$ versus $11.4 \%$ at $p=0.01$ and $10.5 \%$ versus $3.8 \%$ at $p=0.05$, respectively), the difference with the corresponding values registered in the control group significant. As for the remaining hormones studied, there were no statistically significant differences revealed in their concentrations, however, the group with lactobacilli had a higher incidence of hyperprolactinemia (Fig. 3).

Compared to the control group, patients of the treatment group had their ejaculate samples more saturated with bacteria, the content measured as the total bacterial load $\left(10^{4.5 \pm 0.6}\right.$ versus $10^{4.2 \pm 0.9}$, respectively, $\left.p<0.01\right)$.

The results of RT-PCR examination (Fig. 4) show that the majority of identifiable microorganisms were registered in the treatment group more often than in the patients that had no lactobacilli detected. The difference in the incidence was significant $(p<0.05)$.
The results of the spermiological study (Fig. 5.) revealed that the more common types of disorder in the treatment group was oligoastenoteratozoospermia $(30.0 \%$ versus $9.3 \%$; $p<0.01$ ) and asthenoteratozoospermia (28.8\% versus $20.0 \% ; p=0.1$ ). In the control group, the disorders diagnosed significantly more often were normozoospermia (42.7\% versus $25.0 \% ; p=0.01$ ) and isolated teratozoospermia (20.0\% versus $7.5 \% ; p=0.01$ ). Asymptomatic leukospermia was twice as common in the control group as in the treatment group (26.7\% versus $13.8 \%$; $p=0.03$ ). The analysis of the key spermogram indicators (Table 2) showed that in the treatment group the motility, morphology of spermatozoids, as well as sperm concentration, were significantly worse compared to the control group.

\section{DISCUSSION}

There is an opinion that lactobacilli in men can only exist as transient flora. However, as registered in the clinical practice, some patients had Lactobacillus spp. in their ejaculate and reported over a month of sexual abstinence or strict use of barrier contraception, which minimizes the chance that such bacteria are transient in them. This research, in contrast with the pilot study [27], proved the hypothesis about the association between hyperestradiolemia and appearance of Lactobacillus spp. in the ejaculate. In the treatment group, leukospermia was a less common diagnosis than in the control group, which is probably related to the higher incidence of prostate acinus obstruction or fibrosis cases [30]. We found the ejaculate samples of the treatment group patients to be greatly contaminated with bacteria compared to those

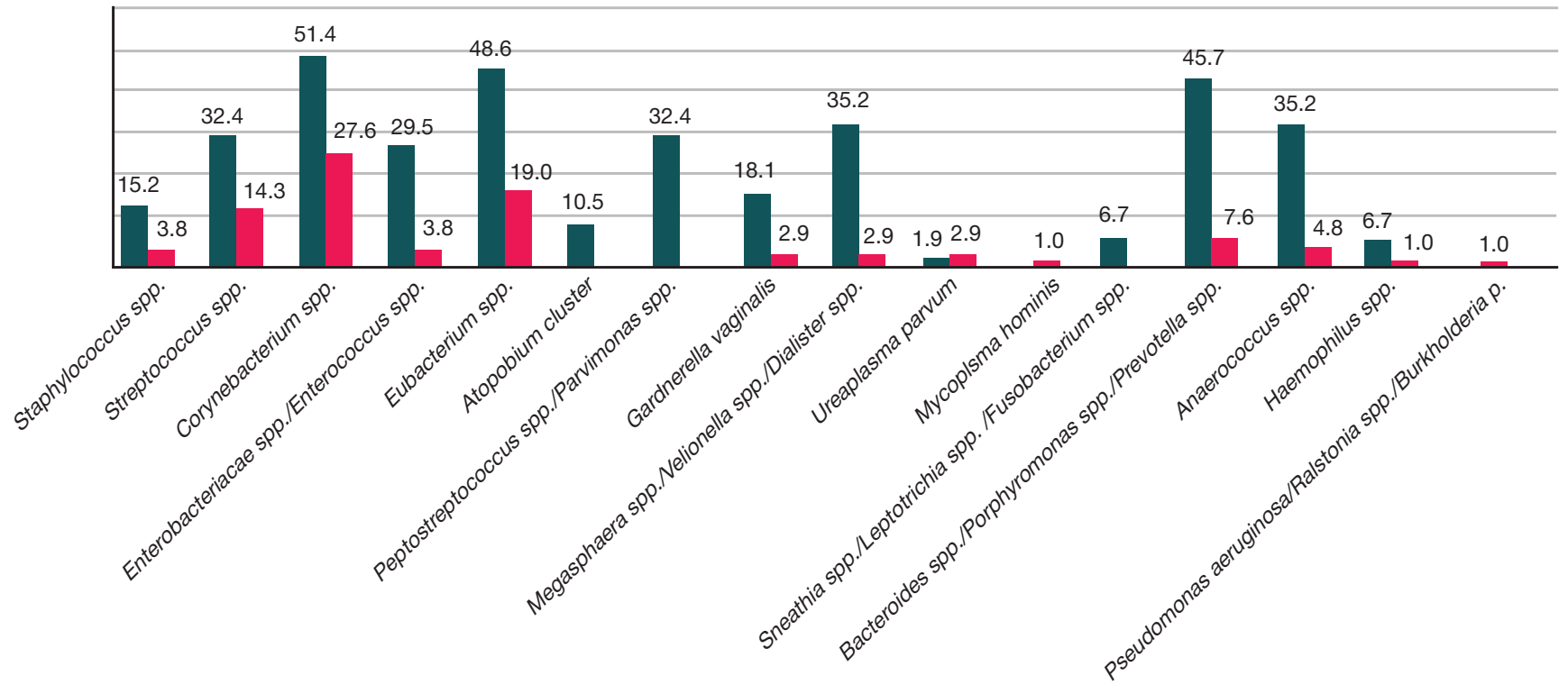

Group of men with Lactobacillus spp., $n=105$

Group of men with normal flora, $n=105$

Fig. 4. The frequency of occurrence of microorganisms in the ejaculate as detected by RT-PCR, two compared groups 


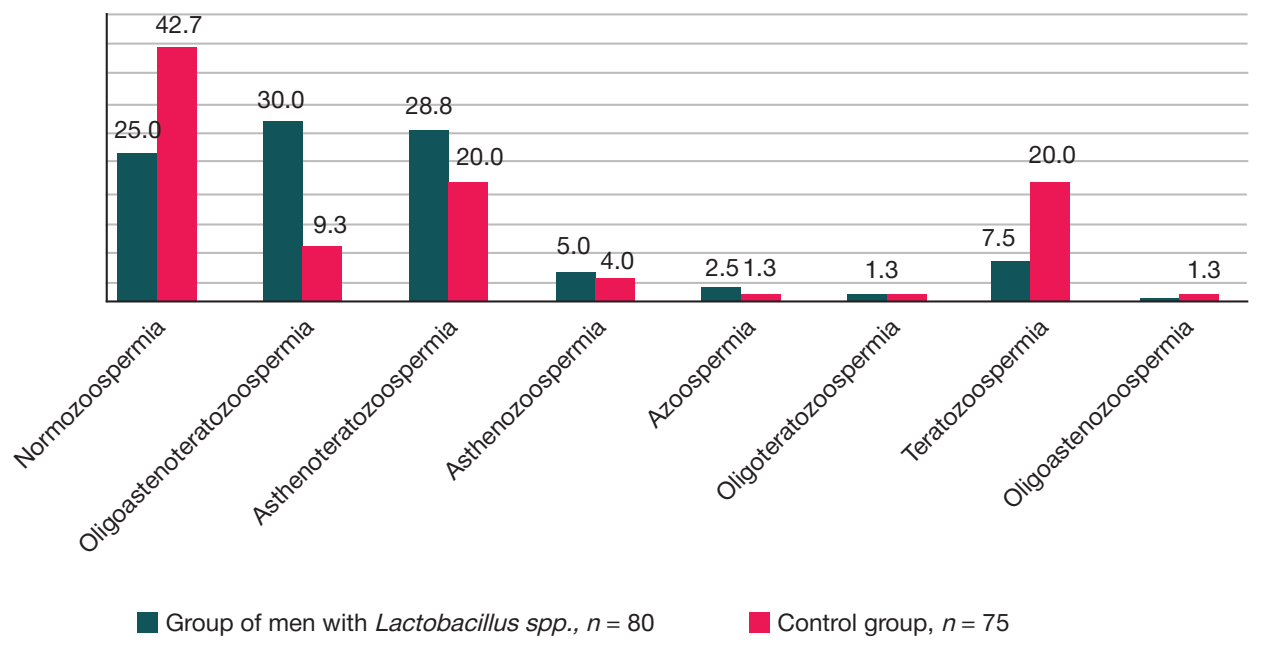

Fig. 5. Changes in spermogram values, two compared groups

of the control group $(p<0.05)$, which can be explained by hyperestradiolemia, increased levels of SHBG and prolactin, since the latter dampen biological activity of testosterone. One of the SHBG growth mechanisms is associated with an increased level of estradiol in blood; it often is a signal of "latent hyperestradiolemia", the latency here meaning the indicators remain within the reference range. The increased level of lactobacilli can be considered as a protectivecompensatory mechanism triggered to maintain normal ejaculate microbiome and prevent genital tract invasion with opportunistic pathogenic microorganisms [6, 21, 23].

In our opinion, subject to strict adherence to the rules of preparation for RT-PCR ejaculate examination, including sexual abstinence or barrier contraception for at least three days, the detection of Lactobacillus spp. in the titer of $L g \geq 10^{3}$ can be regarded as an additional reason to investigate

the concentrations of estradiol, prolactin, progesterone and SHBG.

The analysis of the data obtained does not allow deriving whether the lactobacilli play a negative or a positive role; this may be subject of further research that, employing RT-PCR, will establish the amount of Lactobacillus spp. and determine the type of this group of microorganisms.

\section{CONCLUSIONS}

Thus, Lactobacillus spp. bacteria are more likely to be found in the ejaculate of men with hyperestradiolemia and more severe combined abnormalities as detected by the spermogram. Detection of Lactobacillus spp. in semen can be an additional marker of hormonal imbalance in men, even with the spermogram values being normal.

Table 2. The studied spermogram values in the two compared groups

\begin{tabular}{|l|c|c|}
\hline \multicolumn{1}{|c|}{ Spermogram value } & $\begin{array}{c}\text { Group with Lactobacillus spp. } \\
(n=80), \text { mean } \pm \text { STD }\end{array}$ & $\begin{array}{c}\text { Group without Lactobacillus spp. } \\
(n=75), \text { mean } \pm \text { STD }\end{array}$ \\
\hline Spermatozoa concentration, $\mathrm{mln} / \mathrm{ml}$ & $52.6 \pm 44.8$ & $70.1 \pm 48.2$ \\
\hline $\begin{array}{l}\text { The total number of spermatozoa in the } \\
\text { ejaculate, } \mathrm{mln}\end{array}$ & $167.1 \pm 167.3$ & $221.6 \pm 169.4$ \\
\hline Progressively motile spermatozoa (PR), \% & $25.4 \pm 23.7$ & $40.4 \pm 23.7$ \\
\hline Non-progressively motile spermatozoa, (NP), \% & $11.3 \pm 9.4$ & $12.3 \pm 9.7$ \\
\hline Immobile spermatozoa, (IM), \% & $61.2 \pm 27.8$ & $<.01$ \\
\hline Normal forms, \% & $2.4 \pm 2.1$ & $<.2$ \\
\hline
\end{tabular}

\section{References}

1. Chaplin AV, Rebrikov DV, Boldyreva MN. The human microbiome. Bulletin of RSMU. 2017; (2): 5-13. DOl: 10.24075/brsmu.2017-02-01.

2. Jungwirth JA, Diemer T, Kopa Z, et. al. EAU guidelines on male infertility (C) European Association of Urology. Available from: https://uroweb.org/wp-content/uploads/EAU-Guidelines-onMale-Infertility-2019.pdf (Accessed May 2, 2019).

3. Shhepleva PA, redaktor. Andrologija dlja urologov. M.: MedforumAl'fa, 2019; 424 s. Russia.

4. Aljaev YuG, Glybochko PV, Pushkar DYu, redaktory. Urologija: Rossijskie klinicheskie rekomendacii. M.: Medforum, 2018; 544 s. Russia.

5. Pochernikov DG, Vitvickaja YuG, Boldyreva MN, Galkina IS. Informativnost' biomateriala dlja issledovanija mikrobioty urogenital'nogo trakta muzhchin metodom PCR-RV (pilotnoe issledovanie). Jeksperimental'naja i klinicheckaja urologija. 2019; 2: 128-32. DOI: 10.29188/2222-8543-2019-11-2-128-132. Russia.

6. Monteiro C, Marques PI, Cavadas B, et al. Characterization of microbiota in male infertility cases uncovers differences in seminal hyperviscosity and oligoasthenoteratozoospermia possibly correlated with increased prevalence of infectious bacteria. Am J Reprod Immunol. 2018; 79 (6): e12838. DOI: 10.1111/aji.12838.

7. Voroshilina ES, Zornikov DL, Panacheva EA. Evaluation of the ejaculate microbiota by real-time PCR and culture-based technique. Bulletin of RSMU. 2019; 1: 41-6. DOI: 10.24075/ vrgmu.2019.009.

8. Štšepetova J, Baranova J, Simm J, et al. The complex microbiome from native semen to embryo culture environment in human in vitro fertilization procedure. Reprod Biol Endocrinol. 2020; 18 (1): 
3. DOI: 10.1186/s12958-019-0562-z.

9. Rakhmatulina MR, Galkina IS. Quantitative PCR in diagnosing infectious urogenital pathology. Bulletin of RSMU. 2019; 6: 10710. DOI: $10.24075 /$ vrgmu.2019.088.

10. Borovec SYu. Diagnosticheskaja znachimost' issledovanija mikroflory jejakuljata u bol'nyh hronicheskim bakterial'nym prostatitom metodom PCR-RT «Androflor». V sbornike: Materialy 5-j nauchno-prakticheskoj konferencii urologov Severo-Zapadnogo federal'nogo okruga RF; Sankt-Peterburg, 2019. Urologicheskie vedomosti. 2019; 9: 22-23. Russia.

11. Hou D, Zhou X, Zhong X, Settles ML, Herring J, Wang L, et al. Microbiota of the seminal fluid from healthy and infertile men. Fertil Steril. 2013 Nov; 100 (5): 1261-9. DOl: 10.1016/j.fertnstert.2013.07.1991.

12. Tomaiuolo R, Veneruso I, Cariati F, D'Argenio V. Microbiota and Human Reproduction: The Case of Male Infertility. High Throughput. 2020 Apr 13; 9 (2): pii E10. DOI: 10.3390/ht9020010.

13. Altmäe $\mathrm{S}$, Franasiak JM, Mändar R. The seminal microbiome in health and disease. Nat Rev Urol. 2019 Dec; 16 (12): 703-21. DOI:10.1038/s41585-019-0250-y.

14. Rakhmatulina MR, Boldyreva MN, Lipova EV, Chekmarev AS, Galkina IS. Ocenka mikrobioty soskoba uretry u muzhchin s infekcijami, peredavaemymi polovym putem. Urologija. 2019; 6: 31-37. Russia.

15. Lipova EV, Chekmarev AS, Boldyreva MN. Novyj metod diagnostiki infekcionno-vospalitel'nyh zabolevanij nizhnih otdelov mochepolovogo trakta u muzhchin (test Androflor ${ }^{\circledR}$, Androflor ${ }^{\circledR}$ Skrin). M., 2017; 48 s. Russia.

16. Pochernikov DG, Galkina IS, Postovoytenko NT, Gerasimov AM. A comparative analysis of seminal and vaginal microbiota of married couples by real-time PCR with Androflor and Femoflor reagent kits. Bulletin of RSMU. 2017; 2: 34-39. DOI: 10.24075/ brsmu.2017-02-05.

17. Baranova EE, Bateneva El, Galkina IS, Donnikov AE, Zorina W, Tumbinskaja LV, i dr. PCR v real'nom vremeni: novye vozmozhnosti tehnologii v reshenii reproduktivnyh problem: uchebnoe posobie. M.: DNK-Tehnologija, 2013; 63 s. Russia.

18. Tapilskaja NI, Shahova MA. Pregravidarnaja podgotovka supruzheskoj pary s uchastiem oboih partnerov pri chastyh recidivah bakterial'nogo vaginoza. Lechashhij vrach. 2018; 2: 8287. Russia

19. Chigrinec SV, Brjuhin GV. Svjaz' mikrobioty uretry s kachestvom jejakuljata i soderzhaniem jendokrinnyh disraptorov $v$ semennoj zhidkosti u muzhchin. Andrologija i genital'naja hirurgija. 2018; 19 (4): 60-66. DOI: 10.17650/2070-9781-2018-19-4-60-66. Russia

\section{Литература}

1. Чаплин А. В., Ребриков Д. В., Болдырева М. Н. Микробиом человека. Вестник РГМУ. 2017; (2): 5-13. DOI: 10.24075/ brsmu.2017-02-01.

2. Jungwirth JA, Diemer T, Kopa Z, et. al. EAU guidelines on male infertility (c) European Association of Urology. Available from: https://uroweb.org/wp-content/uploads/EAU-Guidelines-onMale-Infertility-2019.pdf (Accessed May 2, 2019).

3. Щеплева П. А., редактор. Андрология для урологов. М.: Медфорум-Альфа, 2019; 424 с.

4. Аляев Ю. Г., Глыбочко П. В., Пушкарь Д. Ю., редакторы. Урология: Российские клинические рекомендации. М.: Медфорум, 2018; 544 c.

5. Почерников Д. Г., Витвицкая Ю. Г., Болдырева М. Н., Галкина И. С. Информативность биоматериала для исследования микробиоть урогенитального тракта мужчин методом ПЦР-РВ (пилотное исследование). Экспериментальная и клиническая урология. 2019; 2: 128-32. DOI: 10.29188/2222-8543-2019-11-2-128-132.

6. Monteiro C, Marques PI, Cavadas B, et al. Characterization of microbiota in male infertility cases uncovers differences in seminal hyperviscosity and oligoasthenoteratozoospermia possibly correlated with increased prevalence of infectious bacteria. Am J Reprod Immunol. 2018; 79 (6): e12838. DOI: 10.1111/aji.12838.

7. Ворошилина Е. С., Зорников Д. Л., Паначева Е. А. Сравнительное исследование микробиоты эякулята методом количественной
20. Frølund M, WikstroĖm A, Lidbrink P, Abu Al-Soud W, Larsen N, Harder CB, et al. The bacterial microbiota in first-void urine from men with and without idiopathic urethritis. PLoS ONE 2018; 13 (7): e0201380. DOI: 10.1371/journal.pone.0201380

21. Ivanov IB, Kuzmin MD, Gritsenko VA. Microflora of the seminal fluid of healthy men and men suffering from chronic prostatitis syndrome. Int J Androl. 2009; 32 (5): 462-7. DOI:10.1111/j.13652605.2008.00878.x.

22. Baud D, Pattaroni C, Vulliemoz N, Castella V, Marsland BJ, Stojanov M. Sperm Microbiota and Its Impact on Semen Parameters. Front Microbiol. 2019 Feb 12; 10: 234. DOI: 10.3389/ fmicb.2019.00234.

23. Weng SL, Chiu CM, Lin FM, Huang WC, Liang C, Yang T, et al. Bacterial communities in semen from men of infertile couples: metagenomic sequencing reveals relationships of seminal microbiota to semen quality. PLoS One. 2014 Oct 23; 9 (10): e110152. DOI: 10.1371/journal.pone.0110152.

24. Nickel JC. Chronic prostatitis: an infectious disease? Infect Urol. 2000; 13 (2): 31-8.

25. Kogan Ml, Ibishev KS, Cherny AA, Naboka YL, Krakhotkin DV, Krainiy PA, et al/. 244 Analysis of microbiome prostatic secretion in depending of levels total testosterone in blood serum. The Journal of Sexual Medicine. 2018; 15 (7, Suppl 3): 219. DOl: https://doi.org/10.1016/j.jsxm.2018.04.209.

26. Ho C-H, Fan C-K, Yu H-J, Wu C-C, Chen K-C, Liu S-P, et al. Testosterone suppresses uropathogenic Escherichia coli invasion and colonization within prostatecells and inhibits inflammatory responses through JAK/STAT-1 signaling pathway. PLOS One. 2017 Jun 30; 12 (6): e0180244. DOI:10.1371/journal. pone.0180244.

27. Pochernikov DG, Postovojtenko NT, Galkina IS, avtory. Sposob diagnostiki narushenij gormonal'nogo fona u muzhchin. Patent RF \# 2715565. 02.03.2020. Bjul. \# 7. Russia.

28. Instrukcija po primeneniju nabora reagentov dlja issledovanija mikroflory urogenital'nogo trakta muzhchin metodom PCR v rezhime real'nogo vremeni Androflor (OOO NPO «DNK-Tehnologija»). Registracionnoe udostoverenie \# RZN 20164490. Available from: http:www.dna-technology.ru/information/aboutamethod/. Russia.

29. WHO laboratory manual for the examination and processing of human semen. 5th edn. Geneva, 2010. 271 p.

30. Cukanov AYu, Satybaldin DO, Semikina SP. Povyshenie rezul'tativnosti mikrobiologicheskogo issledovanija jejakuljata pri diagnostike prichin muzhskogo besplodija. Urologija. 2019; 6: 26-30. Available from: https://dx.doi.org/10.18565/urology.2019.6.26-30. Russia.
ПЦР и культуральным методом. Вестник РГМУ. 2019; 1: 44-9. DOI: 10.24075/vrgmu.2019.009.

8. Štšepetova J, Baranova J, Simm J, et al. The complex microbiome from native semen to embryo culture environment in human in vitro fertilization procedure. Reprod Biol Endocrinol. 2020; 18 (1): 3. DOI: 10.1186/s12958-019-0562-z.

9. Рахматулина М. Р., Галкина И. С. Диагностика инфекционной урогенитальной патологии методом количественной ПЦР. Вестник РГМУ. 2019; 6: 114-8. DOI: 10.24075/vrgmu.2019.088.

10. Боровец С. Ю. Диагностическая значимость исследования микрофлоры эякулята у больных хроническим бактериальным простатитом методом PCR-RT «Андрослор». В сборнике: Материалы 5-й научно-практической конференции урологов Северо-Западного федерального округа РФ; СанктПетербург, 2019. Урологические ведомости. 2019; 9: 22-23.

11. Hou D, Zhou X, Zhong X, Settles ML, Herring J, Wang L, et al. Microbiota of the seminal fluid from healthy and infertile men. Fertil Steril. 2013 Nov; 100 (5): 1261-9. DOI: 10.1016/j.fertnstert.2013.07.1991.

12. Tomaiuolo R, Veneruso I, Cariati F, D'Argenio V. Microbiota and Human Reproduction: The Case of Male Infertility. High Throughput. 2020 Apr 13: 9 (2): pii E10. DOI: 10.3390/ht9020010.

13. Altmäe S, Franasiak JM, Mändar R. The seminal microbiome in health and disease. Nat Rev Urol. 2019 Dec; 16 (12): 703-21. DOI:10.1038/s41585-019-0250-y. 
14. Рахматулина М. Р., Болдырева М. Н., Липова Е. В., Чекмарев А. С., Галкина И. С.. Оценка микробиоты соскоба уретры у мужчин с инфекциями, передаваемыми половым путем. Урология. 2019; 6: 31-37.

15. Липова Е. В., Чекмарев А. С., Болдырева М. Н. Новый метод диагностики инфекционно-воспалительных заболеваний нижних отделов мочеполового тракта у мужчин (тест «Андрофллор ${ }^{\oplus}$, «Андрофрлор ${ }^{\circledR}$ Скрин»). М., 2017; 48 с.

16. Почерников Д. Г., Галкина И. С., Постовойтенко Н. Т., Герасимов А. М. Сравнительный анализ биотопа эякулята и цервикального канала методом ПЦР-РВ с тестами «Андрофлор» и «Фемофрлор» в супружеских парах. Вестник РГМУ. 2017; 2: 37-41. DOI: 10.24075/brsmu.2017-02-05.

17. Баранова Е. Е., Батенева Е. И., Галкина И. С., Донников А. Е., Зорина В. В., Тумбинская Л. В. и др. ПЦР в реальном времени: новые возможности технологии в решении репродуктивных проблем: учебное пособие. М.: ДНК-Технология, 2013; 63 с.

18. Тапильская Н. И., Шахова М. А. Прегравидарная подготовка супружеской пары с участием обоих партнеров при частых рецидивах бактериального вагиноза. Лечащий врач. 2018; 2: 82-87.

19. Чигринец С. В., Брюхин Г. В. Связь микробиоты уретры с качеством эякулята и содержанием эндокринных дисрапторов в семенной жидкости у мужчин. Андрология и генитальная хирургия. 2018; 19 (4): 60-66. DOI: 10.17650/2070-9781-201819-4-60-66.

20. Frølund M, WikstroÈm A, Lidbrink P, Abu Al-Soud W, Larsen N, Harder CB, et al. The bacterial microbiota in first-void urine from men with and without idiopathic urethritis. PLOS ONE 2018; 13 (7): e0201380. DOI: 10.1371/journal.pone.0201380.

21. Ivanov IB, Kuzmin MD, Gritsenko VA. Microflora of the seminal fluid of healthy men and men suffering from chronic prostatitis syndrome. Int J Androl. 2009; 32 (5): 462-7. DOl:10.1111/j.13652605.2008.00878.x.

22. Baud D, Pattaroni C, Vulliemoz N, Castella V, Marsland BJ, Stojanov M. Sperm Microbiota and Its Impact on Semen
Parameters. Front Microbiol. 2019 Feb 12; 10: 234. DOI: 10.3389/ fmicb.2019.00234.

23. Weng SL, Chiu CM, Lin FM, Huang WC, Liang C, Yang T, et al. Bacterial communities in semen from men of infertile couples: metagenomic sequencing reveals relationships of seminal microbiota to semen quality. PLoS One. 2014 Oct 23; 9 (10): e110152. DOI: 10.1371/journal.pone.0110152.

24. Nickel JC. Chronic prostatitis: an infectious disease? Infect Urol. 2000; 13 (2): 31-8.

25. Kogan MI, Ibishev KS, Cherny AA, Naboka YL, Krakhotkin DV Krainiy PA, et al/. 244 Analysis of microbiome prostatic secretion in depending of levels total testosterone in blood serum. The Journal of Sexual Medicine. 2018; 15 (7, Suppl 3): 219. DOI: https://doi.org/10.1016/j.jsxm.2018.04.209.

26. Ho C-H, Fan C-K, Yu H-J, Wu C-C, Chen K-C, Liu S-P, et al. Testosterone suppresses uropathogenic Escherichia coli invasion and colonization within prostatecells and inhibits inflammatory responses through JAK/STAT-1 signaling pathway. PLOS One. 2017 Jun 30; 12 (6): e0180244. DOI:10.1371/journal. pone. 0180244 .

27. Почерников Д. Г., Постовойтенко Н. Т., Галкина И. С., авторы. Способ диагностики нарушений гормонального фона у мужчин. Патент РФ № 2715565. 02.03.2020. Бюл. № 7.

28. Инструкция по применению набора реагентов для исследования микрофлоры урогенитального тракта мужчин методом ПЦР в режиме реального времени Андрофлор ${ }^{\circledast}$ (ООО НПО «ДНК-Технология»). Регистрационное удостоверение № Р3Н 20164490. Доступно по ссылке: http:www.dnatechnology.ru/information/aboutamethod/.

29. WHO laboratory manual for the examination and processing of human semen. 5th edn. Geneva, 2010; 271 p.

30. Цуканов А. Ю., Сатыбалдин Д. О., Семикина С. П. Повышение результативности микробиологического исследования эякулята при диагностике причин мужского бесплодия. Урология. 2019; 6: 26-30. Доступно по ссылке: https://dx.doi. org/10.18565/urology.2019.6.26-30. 